\title{
HPLC-EICD: An Useful Tool for the Pursuit of Novel Analytical Strategies for the Detection of Antioxidant Secondary Metabolites
}

\author{
Ian Castro-Gamboa, Carmen L. Cardoso, Dulce H. S. Silva, Alberto J. Cavalheiro, Maysa Furlan \\ and Vanderlan da S. Bolzani*
}

Instituto de Química, Universidade Estadual Paulista, CP 355, 14800-900 Araraquara - SP, Brazil

\begin{abstract}
As células estão continuamente expostas a uma série de fatores que exercem estresse oxidativo o qual gera várias patologias que estão relacionadas a fatores de senescência tais como doenças coronárias, artrites reumática, e câncer. Para combater esse efeito, os organismos vivos desenvolveram uma rede complexa de antioxidantes que agem contra essas espécies radicalares nocivas à vida. Com o intuito de fazer uma bioprospecção de espécies vegetais da Mata Atlântica e Cerrados brasileiros estabelecemos uma metodologia para detetar compostos com atividade antioxidante. A combinação de CLAE a um detetor eletroquímico permitiu a detecção de micromoléculas antioxidantes nos extratos brutos das folhas de Chimmarhis turbinata (DC). Foi possível detectar e identificar nas matrizes naturais os compostos responsáveis após comparação com padrões isolados da mesma espécie.
\end{abstract}

Living cells are continuously exposed to a variety of challenges that exert oxidative stress and are directly related with senescence and the onset of various pathological conditions such as coronary heart disease, rheumatoid arthritis and cancer. Nevertheless, living organisms have developed a complex antioxidant network to counteract reactive species that are detrimental to life. With the aim of bio-prospecting plant species from the Brazilian Cerrado and Atlantic Forest, we have established a methodology to detect secondary antioxidant metabolites in crude extracts and fractions obtained from plant species. Combining HPLC with an electrochemical detector allowed us to detect micromolecules that showed antioxidant activities in Chimarrhis turbinata (DC) leaf extracts. Comparison with purified flavonoid standards led us to identify the compounds in their natural matrices giving valuable information on their antioxidant capacity.

Keywords: antioxidant, HPLC-ElCD, reactive-oxygen-species, flavonoids

\section{Introduction}

Oxygen-derived free radicals such as the superoxide anion radical and hydroxyl radical are thought to be linked to the onset of various pathological conditions such as coronary heart disease, rheumatoid arthritis and cancer. ${ }^{1-3}$ Living cells, including those of man, animals and plants, are continuously exposed to a variety of challenges that exert oxidative stress. These could stem from endogenous sources through normal physiological processes such as mitochondrial respiration. Alternatively, they could result from exogenous sources such as exposure to pollutants and ionizing irradiation. ${ }^{4,5}$

Oxidative stress arises in a biological system after an increased exposure to oxidants, a decrease in the

\footnotetext{
* e-mail: bolzaniv@iq.unesp.br
}

antioxidant capacity of the system, or both. This is often associated with the generation of reactive oxygen species (ROS), including free radicals, which are strongly implicated in the pathophysiology of diseases. ${ }^{6-8}$ Cells are equipped with several defense systems, which act through a variety of mechanisms. ${ }^{9}$ These can be categorized into protection via enzymatic activities and protection through low-molar mass antioxidants (LMMAs).$^{10}$

The LMMA family consist of many compounds, which act as a direct chemical scavengers neutralizing ROS components or indirectly through transition metal chelation. ${ }^{11}$ LMMAs are small molecules that frequently infiltrate cells, accumulate in specific compartments associated with oxidative damage and then are regenerated by the cell. In human tissues, cellular LMMAs are obtained from various sources. Glutathione (GSH), nicotinamide adenine dinucleotide (reduced form), and carnosine ${ }^{12}$ are synthesized by the cells; uric acid ${ }^{13}$ and bilirubin ${ }^{14}$ are 
waste products of cellular metabolism, and ascorbic acid, tocopherols and polyphenols are antioxidants obtained from the diet. ${ }^{15}$

Flavonoids and phenolic acids are ubiquitous bioactive compounds found in plant tissues. ${ }^{16}$ They can be arranged in several structural classes including anthocyanins, flavones, flavan-3-ols (catechins), flavonols and tannins. These micromolecules share the same basic structure consisting of two aromatic rings joined in a chroman structure by a three-carbon unit: $\mathrm{C}_{6}-\mathrm{C}_{3}-\mathrm{C}_{6}$. Phenolic acids in plant foods and beverages comprise mainly derivatives of hydroxybenzoic and hydroxycinnamic acids. ${ }^{17}$ The diversity in structure and reactivity among different flavonoids and phenolic acids are mainly due to variations in the patterns of oxy-substituents on their aromatic rings. ${ }^{18}$

Both flavonoids and phenolic acids are closely associated with the sensory attributes of fresh and processed plant foods. However, increasing attention has been given to these classes because of their potential antioxidant activity that may exert cardioprotective effects in humans. ${ }^{19}$ Thus, it was shown that intake of flavonoids, especially quercetin found in onions, tea and apples, was inversely related to coronary heart disease mortality. Further, it has been suggested that the high amount of flavonoids and phenolic compounds consumed in red wine may explain the reduced coronary heart disease mortality in certain regions of France..$^{20,21}$

Evidence has shown that oxidation of low-density lipoprotein (LDL) leads to atherogenic reactions, and hence increases coronary heart disease mortality. ${ }^{22,} 23$ Antioxidants that inhibit LDL oxidation may thus reduce atherogenesis. Currently, there is no direct evidence that flavonoids and phenolic acids reduce LDL oxidation in vivo but several studies have shown that these phenolic compounds have the capacity to reduce LDL oxidation in vitro: micromolar concentrations of phenolic compounds in wine and grape juice were thus demonstrated to inhibit oxidation of human LDL in vitro. ${ }^{24}$

Several methods for measuring the total antioxidant capacity of biological samples, including blood plasma, body fluids and plant extracts, have been proposed and reviewed..$^{25-28}$ These are related to the capacity of a sample to compete for and scavenge a specific ROS. They provide useful information, which is thought sufficient for the evaluation of the overall antioxidant profile of the biological fluid, tissue homogenate, or plant extract. Recently, electrochemical detection (ElCD) has given good results for the detection of molecules with antioxidant properties, ${ }^{29,30}$ based on their electrochemical behavior. Their on-line determination has been successfully achieved through use of an ElCD, which is widely used as a coupled detector in HPLC separations. With the aim of bio-prospecting plant species from the Brazilian Cerrado, Atlantic Forest and Amazon regions, we have established a methodology to detect antioxidant molecules based on HPLC-ElCD. To select the lead plant extracts, we did a prior screening using the bleaching of $\beta$-carotene-TLC autographic assay ${ }^{31}$ and also cyclic voltammetry ${ }^{32}$ for detecting any electrochemical activity. One of the species selected in this screening was Chimarrhis turbinata (DC) (Rubiaceae).

This plant is widely spread from Central America and the Caribbean through tropical South America, mostly concentrated in the Amazon region. Their light and resistant wood is used for crafting tools as oars, this usage being related to the etymology of its popular name: "pau-deremo". Rubiaceae species are well known for their biological activities and medicinal uses, bearing metabolites such as flavonoids and indole alkaloids, both chemotypes known to have potential biological activities. The latter are considered taxonomical markers of the Cinchonoideae sub-family within Rubiaceae. ${ }^{33-35}$

\section{Experimental}

\section{Instrumental}

The analytical methodology was developed using a VARIAN STAR 9090 ElCD (Rotterdam, Holland) composed of a glassy carbon working electrode, an $\mathrm{Ag}$ / $\mathrm{AgCl}$ reference electrode and an in situ $\mathrm{Ag} / \mathrm{AgCl}$ electrode. As a complementary detector a VARIAN PROSTAR 310 UV/Vis detector (Walnut Creek, CA, USA) set at $270 \mathrm{~nm}$ was used. A Rheodyne injector (Coxati, CA), with a $20 \mu \mathrm{L}$ loop and a VARIAN 210 HPLC pump as solvent delivery module were used. The determination of the optimal potential to evaluate the crude extracts was obtained through a hydrodynamic voltammogram. Separation of the analytes was carried on a Phenomenex ${ }^{\circledR}$ (Torrance, CA, USA), ODS LUNA; $5 \mu$ column ( 250 x $4.60 \mathrm{~mm})$. The separation did not require a buffer solution, but was greatly improved by the use of acetic acid (Merck, Poole, UK) $(0.05 \% \mathrm{v} / \mathrm{v})$. The isocratic phase was prepared by mixing acetonitrile 15\% v/v; (HPLC grade, Mallinckrodt, Paris, KY, USA) with ultra pure water $85 \%$ v/v, obtained by passing redistilled water through a Milli-Q system (Millipore, Watford, UK). All the separations were carried out at $30{ }^{\circ} \mathrm{C}$ a temperature achieved through an oven coupled to the ElCD.

The extract from Chimarrhis turbinata (DC) leaves was obtained through three distinct macerations of the dried and powered material with $\mathrm{EtOH}: \mathrm{H}_{2} \mathrm{O}$ (8:2). All solvents 
used for extractions were of analytical grade (Mallinckrodt, Paris, Kentucky, USA). After concentration of the extract using a vacuum rotatory evaporator (Büchi, Falwil, Switzerland), the sample was then submitted to prepurification using a Sep-Pak ${ }^{\circledR}$ (ODS) (Waters, Milford, Massachusetts, USA) cartridge with elution using $100 \%$ acetonitrile. The resulting filtered sample was injected into the column for the detection of any electrochemically active component.

\section{Plant material}

The leaves from Chimarrhis turbinata (DC) were collected in "Reserva do Viro", Belém - PA, Brazil in February 2000 and the specimen was identified by Dr. Inês Cordeiro. A voucher (number Cord-2367) was deposited in the Herbarium of the Botanic Garden, São Paulo, Brazil.

\section{Results and Discussion}

Prior to the analysis, it was necessary to establish an optimal potential for the analytes. Thus, solutions $\left(100 \mathrm{mgL}^{-1}\right)$ of catechin (1), rutin (2), chlorogenic acid caffeoyl ester (3) previously isolated and identified from C.turbinata (Figure 1) were prepared. Each standard compound $(20 \mu \mathrm{L})$ was injected at several working electrode potentials ranging from -2.00 to $2.00 \mathrm{~V}$ and chromatograms were recorded at $0.05 \mathrm{~V}$ intervals (Figure 2). The UV/Vis detector was set at $270 \mathrm{~nm}$, which was the best wavelength for the absorption of the flavonoids and the $\mathrm{C}_{6}-\mathrm{C}_{3}$ derivatives used as standards.

From the analyses the optimal working potential was determined to range between $0.80 \mathrm{~V}$ and $0.60 \mathrm{~V}$. Thus the analytical conditions for the crude extracts were improved, aiming to enhance chromatographic resolution. Crude extracts from C.turbinata leaves were injected mostly from the ethyl acetate, methanol and aqueous phases. These are known to be rich in flavonoids an other phenolic metabolites that are usually electrochemically active. Initially it was noted that most of the peaks were broad, suggesting a possible keto-enolic equilibrium of the analytes. We thus used a $0.05 \%(\mathrm{v} / \mathrm{v})$ of acetic acid in water, obtaining great enhancement in the peak profiles as shown in Figure 3.

In the search of a better mobile phase methanol was used but with little success when compared with acetonitrile mixtures. In all chromatographic separations the presence of a buffer solution was not required since we obtained a good cell current and a steady base line for the ElCD. The best chromatographic conditions obtained for the crude extracts were mobile phase water:acetonitrile; $85: 15 \mathrm{v} / \mathrm{v}$, flow rate: $0.80 \mathrm{~mL} / \mathrm{min} ; 0 \%$ offset, digital filter set at $0.1 \mathrm{~s}$, range $5 \mathrm{~mA}$ and an oven temperature of $30^{\circ} \mathrm{C}$. The identification of peaks was based on comparison of

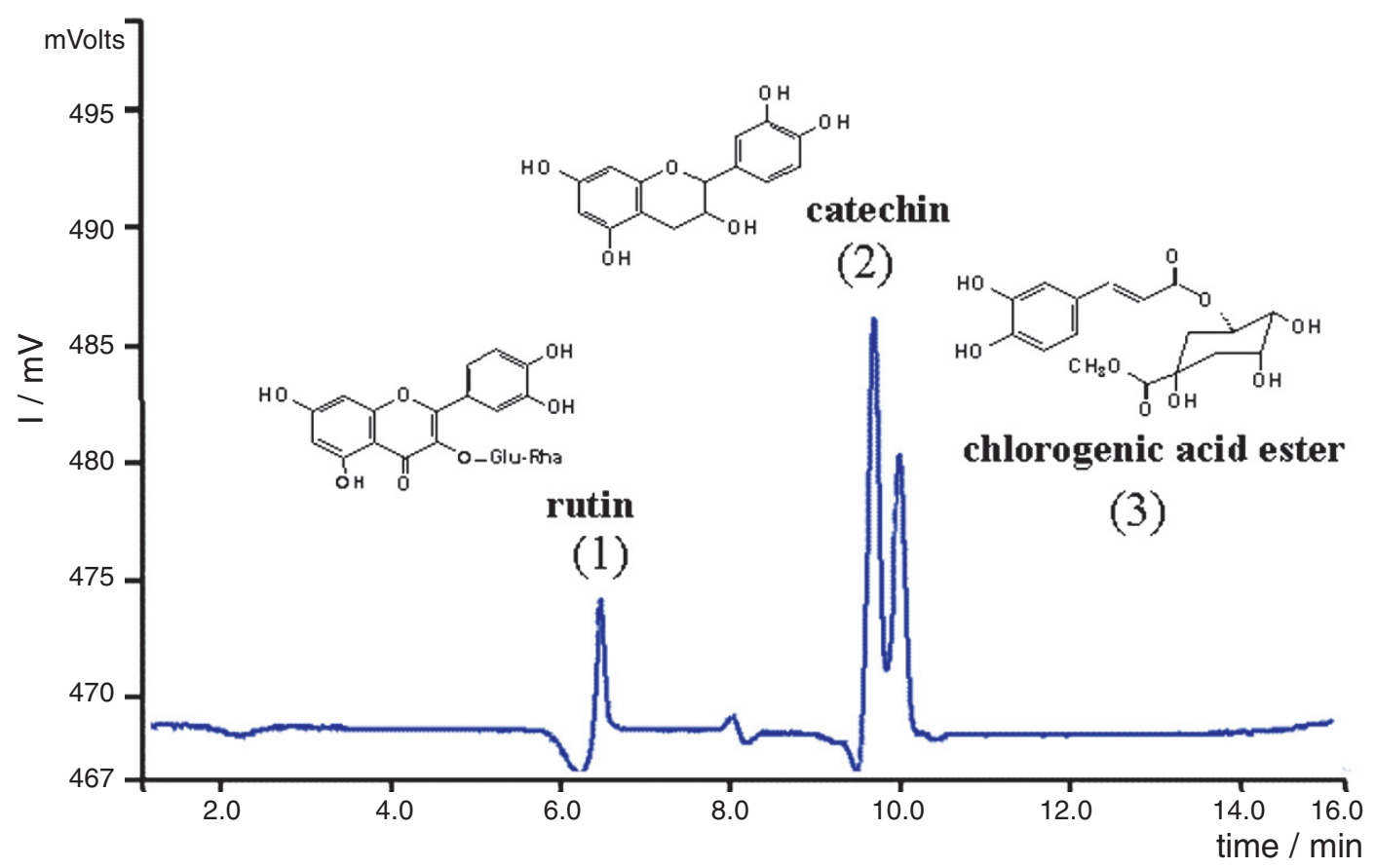

Figure 1. Chromatogram of a mixture of rutin, catechin and chlorogenic acid, isolated from C.turbinata using ElCD. Separation carried out on

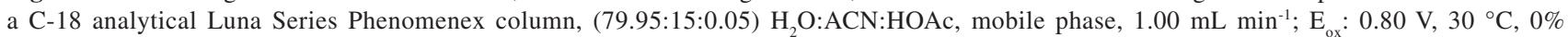
offset, digital filter set at $0.1 \mathrm{~s}$, range $5 \mathrm{~mA}$. 


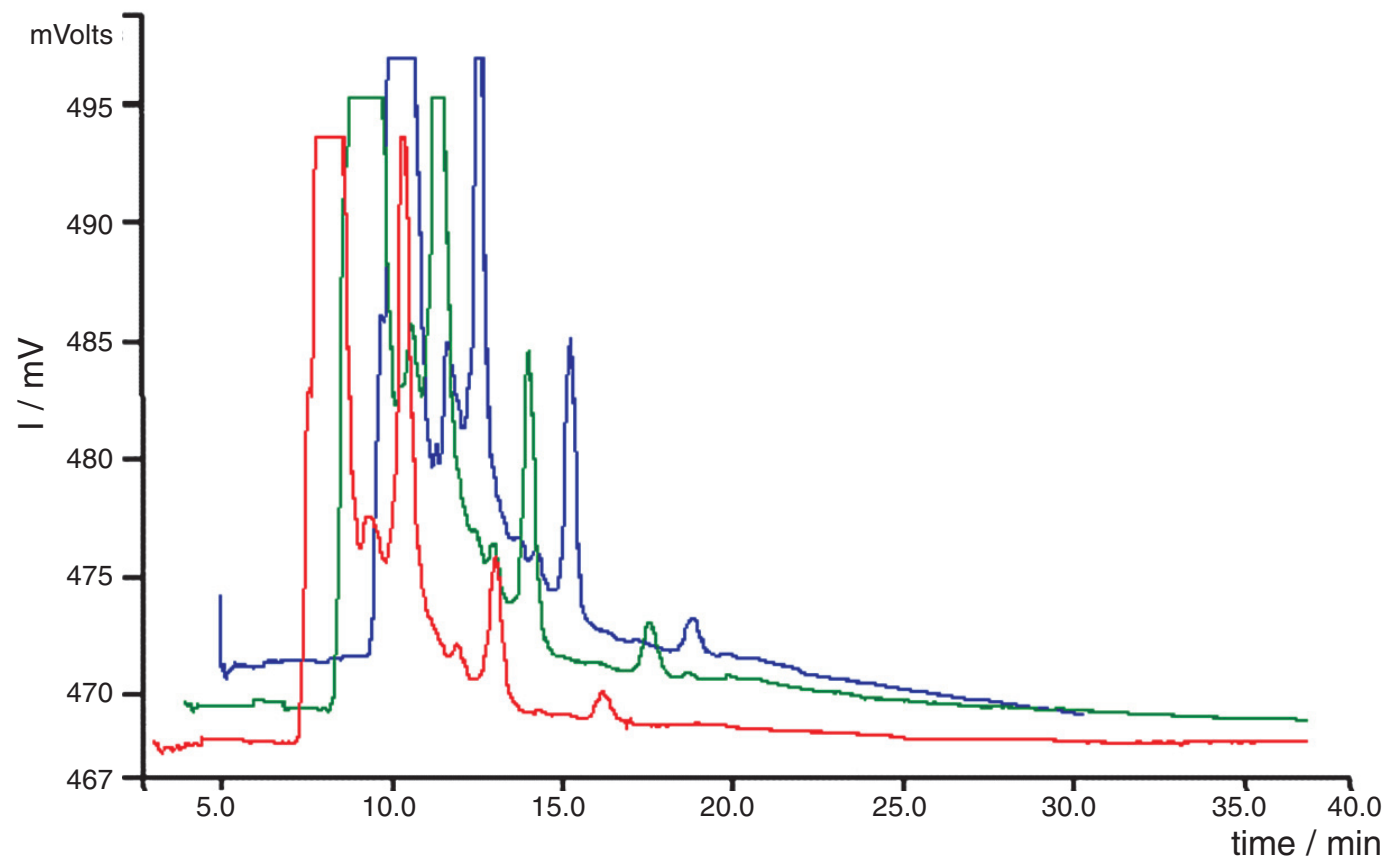

Figure 2. Hydrodynamic voltammogram of a mixture of rutin, catechin and chlorogenic acid ester, isolated from C.turbinata using ElCD and varying the working electrode potentials: left to right 0.80, 0.60 and $0.40 \mathrm{~V}$. Separation carried out on a C-18 analytical Luna Series Phenomenex column, (74.95:25:0.05) $\mathrm{H}_{2} \mathrm{O}: \mathrm{ACN}: \mathrm{HOAc}$, mobile phase, $1.00 \mathrm{~mL} \mathrm{~min}^{-1}$; $\mathrm{E}_{\mathrm{ox}}: 0.80 \mathrm{~V}, 30{ }^{\circ} \mathrm{C}, 0 \%$ offset, digital filter set at $0.1 \mathrm{~s}$, range $5 \mathrm{~mA}$.
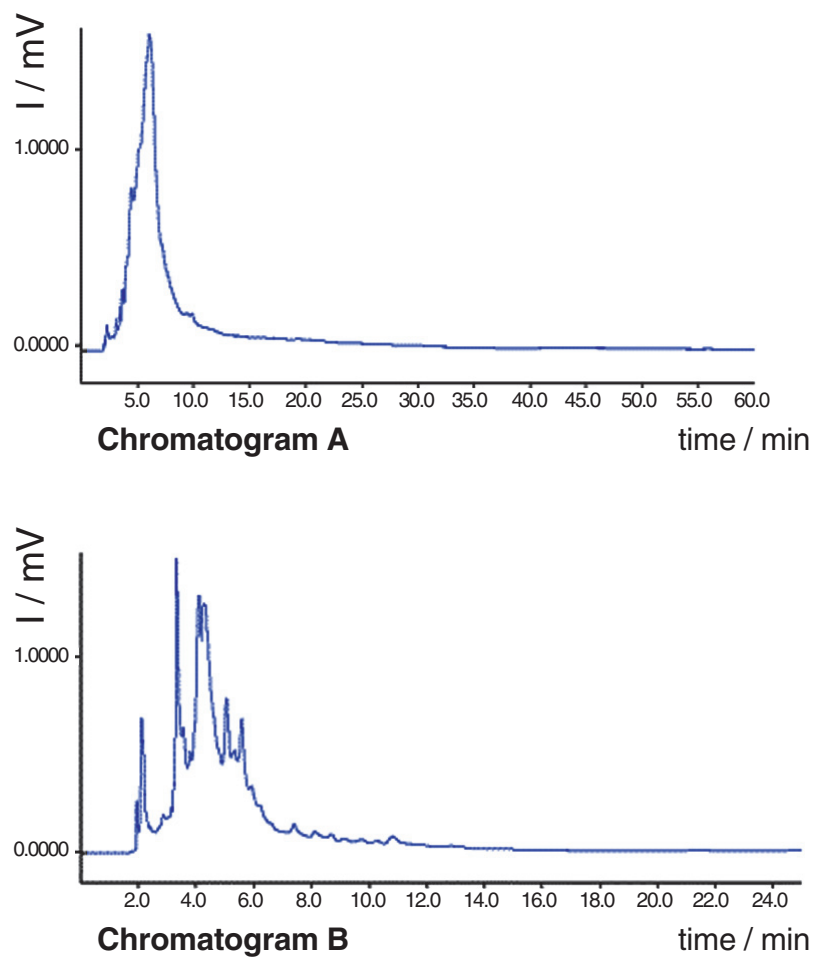

Figure 3. Enhancement of the peaks profiles from a crude leaf extracts of C.turbinata, using acetic acid (0.05\% v/v). Cromatogram $\mathrm{A}$ is without acid and cromatogram B is with acetic acid Separation carried out on a C-18 analytical Luna Series Phenomenex column, (75:25) $\mathrm{H}_{2} \mathrm{O}: \mathrm{ACN}$, mobile phase, $1.00 \mathrm{~mL} \mathrm{~min}^{-1} ; \mathrm{E}_{\mathrm{ox}}: 0.80 \mathrm{~V}, 30{ }^{\circ} \mathrm{C}$, $0 \%$ offset, digital filter set at $0.1 \mathrm{~s}$, range $5 \mathrm{~mA}$. retention times and co-injections of pure compounds (Table 1).

Table 1. Retention times observed for the standards isolated from C.turbinata, under the best chromatographical conditions achieved

\begin{tabular}{lc}
\hline Compound & Retention Time/min \\
\hline catechin (1) & 8.80 \\
rutin $(\mathbf{2})$ & 12.90 \\
chlorogenic acid ester $(\mathbf{3})$ & 58.11 \\
\hline
\end{tabular}

Once the best chromatographic conditions were established for the separation of the crude sample, we compared the retention times of the electrochemically active peaks with those shown by the standards (Figures 4, 5 and 6), with the presence of these micromolecules being manifest in the matrices of the three crude extracts.

\section{Conclusions}

The proposed screening method using HPLC-ElCD is useful for the detection of antioxidants because of its high sensitivity and ease handling. The method may be advantageous for the sensitive determination of antioxidants in complex matrices. The detection limit of the methodology depends directly on the ElCD sensitivity, 


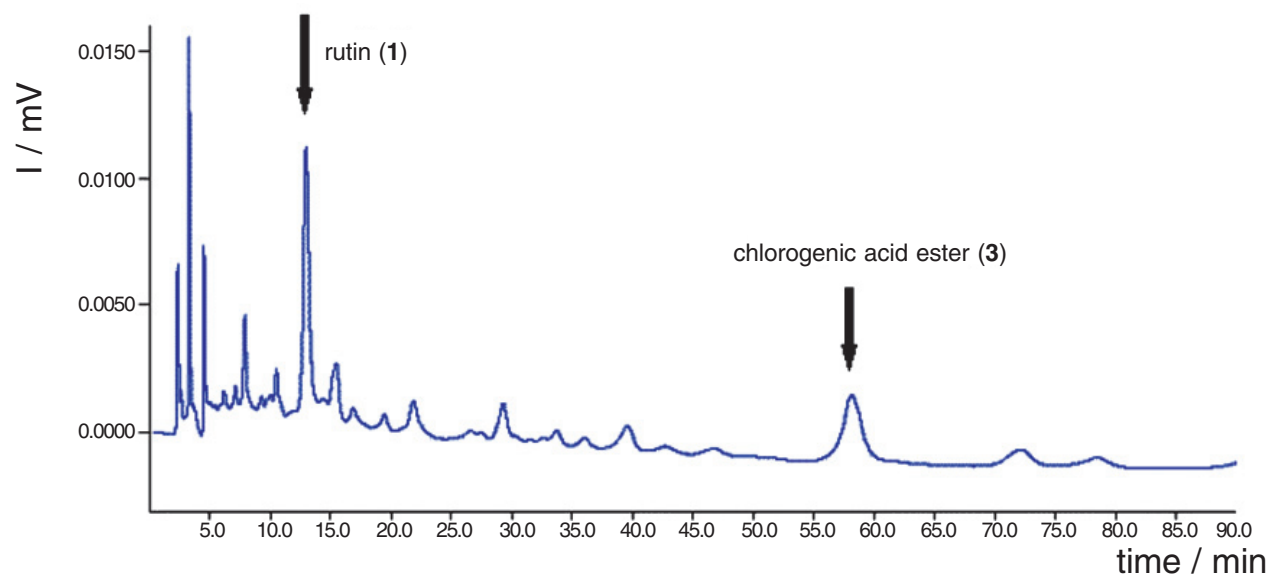

Figure 4. Chromatogram showing the presence of $\mathbf{1}$ and $\mathbf{3}$ in the ethyl acetate fraction from leaves of C.turbinata. Separation carried out on a C-18 analytical Luna Series Phenomenex column, (84.95:15:0.05) $\mathrm{H}_{2} \mathrm{O}: \mathrm{ACN}: \mathrm{HOAc}$, mobile phase, $1.00 \mathrm{~mL} \mathrm{~min}^{-1} ; \mathrm{E}_{\mathrm{ox}}: 0.80 \mathrm{~V}, 30{ }^{\circ} \mathrm{C}, 0 \%$ offset, digital filter set at $0.1 \mathrm{~s}$, range $5 \mathrm{~mA}$.

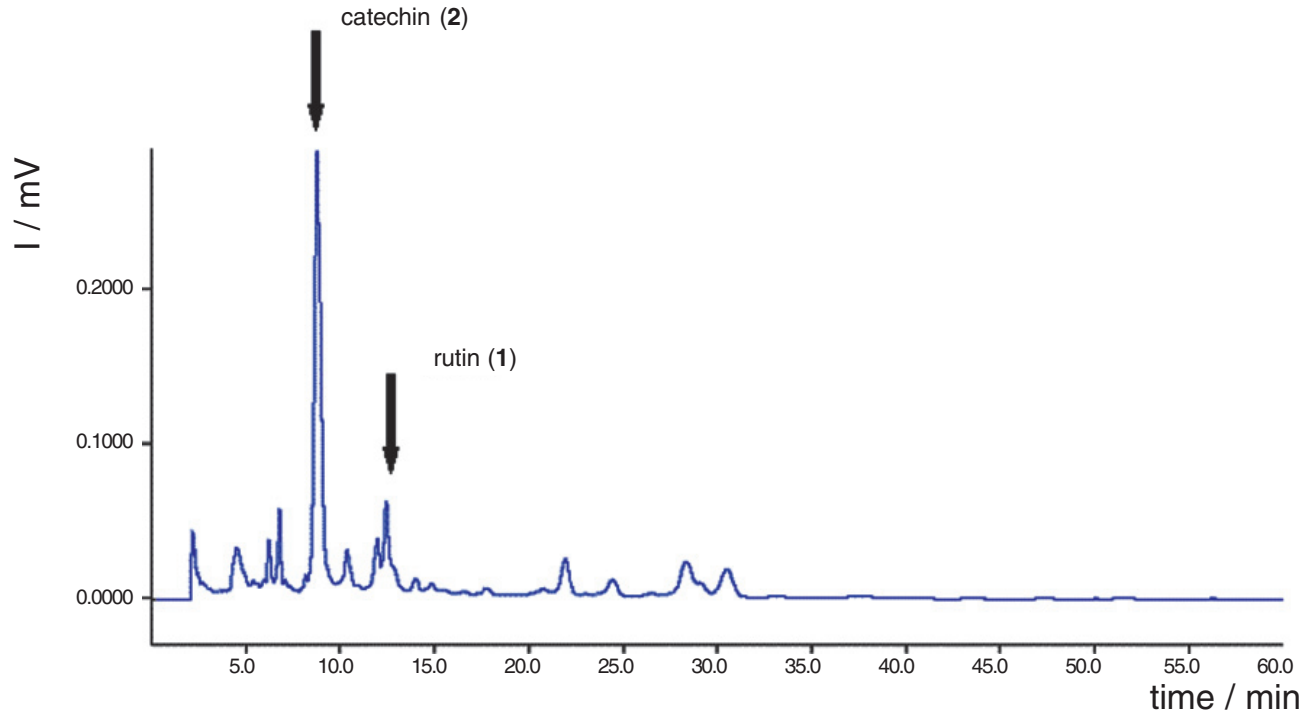

Figure 5. Chromatogram showing the presence of $\mathbf{1}$ and $\mathbf{2}$ in the methanolic fraction from leaves of C.turbinata. Separation carried out on a C18 analytical Luna Series Phenomenex column, (84.95:15:0.05) $\mathrm{H}_{2} \mathrm{O}: \mathrm{ACN}: \mathrm{HOAc}$, mobile phase, $1.00 \mathrm{~mL} \mathrm{~min}^{-1} ; \mathrm{E}_{\mathrm{ox}}: 0.80 \mathrm{~V}, 30{ }^{\circ} \mathrm{C}, 0 \%$ offset, digital filter set at $0.1 \mathrm{~s}$, range $5 \mathrm{~mA}$.

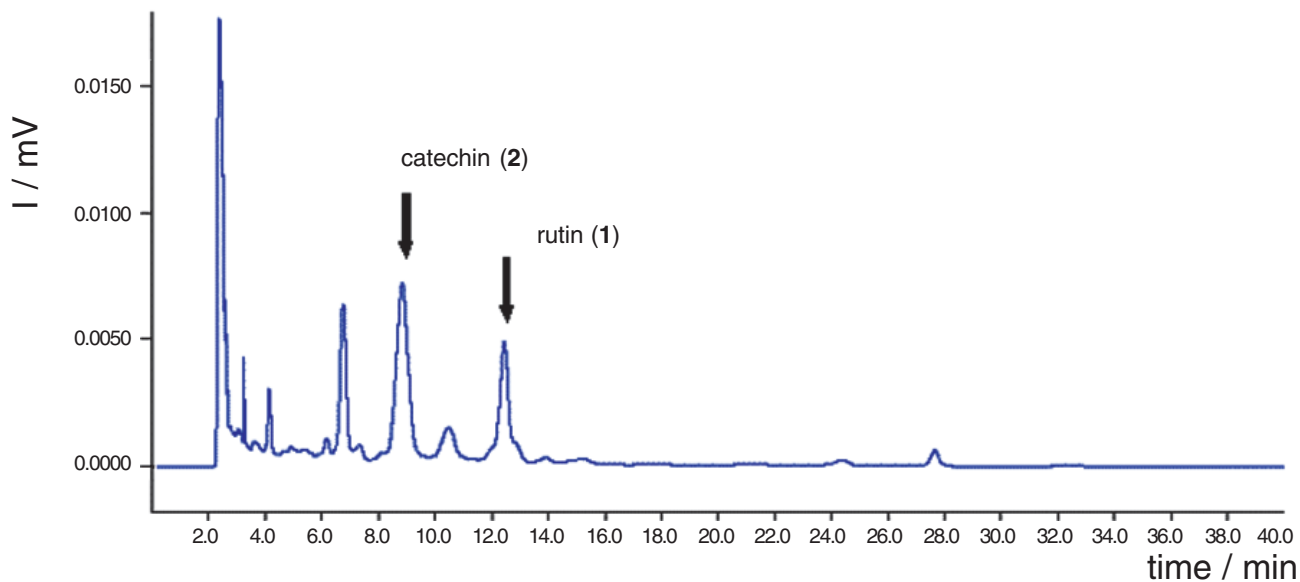

Figure 6. Chromatogram showing the presence of $\mathbf{1}$ and $\mathbf{2}$ in the aqueous fraction from leaves of C.turbinata. Separation carried out on a C-18 analytical Luna Series Phenomenex column, (84.95:15:0.05) $\mathrm{H}_{2} \mathrm{O}: \mathrm{ACN}: \mathrm{HOAc}$, mobile phase, $1.00 \mathrm{~mL} \mathrm{~min}^{-1} ; \mathrm{E}_{\mathrm{ox}}: 0.80 \mathrm{~V}, 30{ }^{\circ} \mathrm{C}, 0 \%$ offset, digital filter set at $0.1 \mathrm{~s}$, range $5 \mathrm{~mA}$. 
which in most cases range from $\mathrm{mV}$ to $\mathrm{pV}$. In the analysis of $C$. turbinata extracts the absence of a buffer solution to stabilize the base line of the electrochemical detector is an important factor, which certainly saves time in the preparation and maintenance of the HPLC and the electrochemical cell. An interesting application of this method is the selection of plant extracts containing LMMA antioxidant molecules for further phytochemical studies and biological evaluation regarding anti-inflammatory, anti-tumoral and other activities, as redox processes are involved in the etiology of a number of pathologies.

\section{Acknowledgements}

This work was supported by the State of São Paulo Research Foundation (FAPESP) within the BIOTA/FAPESP - The Biodiversity Virtual Institute Program (www.biotasp.org.br). VSB and MF are grateful to CNPq for research fellowships. ICG thanks FAPESP for providing a postdoctoral fellowship.

\section{References}

1. Parks, D.A., Bulkey, G.B.; Granger, D.N. Surgery 1983, 94, 428.

2. Hagen, U.; Experientia 1989, 45, 7.

3. Bolli, R.; Jeroudi, M.; Patel, B.; DuBose, B.S.; Lai, E.K.; Roberts, R.P.; MaCay,B.; Proc. Natl. Acad. Sci. USA 1989, 86, 4695.

4. Halliwell, B.; Lancet 1994, 344, 721.

5. Halliwel, B.; Biochemistry 1995, 17, 3.

6. Halliwell, B.; Gutteridge, J.M.C.; Free Radicals in Biology and Medicine; Clarendon Press: Oxford, 1989, p. 86.

7. Gutteridge, J.M.C.; Free Radical Res. Com. 1993, 19, 141.

8. Ames, B.M.; Shigenaga, M.K.; Proc. Natl. Acad. Sci. USA 1993, 90, 7915.

9. Halliwel, B.; Nutr. Rev. 1994, 52, 253.

10. Halliwel, B.; Free Radical Res. Com. 1990, 9, 1.

11. Chevion, M.A.; Free Radical Biol. Med. 1988, 5, 27.

12. Chance, P.A.; Sies, H.; Boveris, A.; Physiol. Rev. 1979, 59, 527.

13. Ames, B.M.; Cathcart, R.; Schwiers, E.; Hochstein, P.; Proc. Natl. Acad. Sci. USA 1981, 73, 6858.

14. Stocker, R.; Yamamoto, Y.; McDonagh, A.; Glazer, A. N.; Ames, B.N.; Science 1987, 235, 1043.
15. Frei, B.; England, L.; Ames, B. N.; Proc. Natl. Acad. Sci. USA 1989, 86, 6377.

16. Hermann, K.; Crit. Rev. Food. Sci. Nutr. 1989, 28, 315.

17. Goodwin, T.W.; Mercer, E.I.; Plant Phenolics, $2^{\text {nd }}$ ed.; Pergamon Press: Oxford, 1992, p. 528.

18. Macheix, J. J.; Fleuriet, A.; Billot, J.; Fruit Phenolics, CRC Press: Boca Ratón, 1990.

19. Kinsella, J.E.; Frankel, E.; German, B., Kanner, J.; Food Technol. 1993, 47, 85.

20. Frankel, E.N.; Kanner, J.; German, J.B.; Parks, E.; Kinsella, J.E.; Lancet 1993, 341, 454.

21. Frankel, E.N.; Waterhouse, A. L.; Teissedre, P.L.; J. Agric. Food Chem. 1995, 43, 890.

22. Esterbauer, H.; Gebicki, J.; Puhl, H.; Jürgens, G.; Free Radical Biol. Med. 1992, 13, 341.

23. Steinberg, D.; Atherosclerosis Rev. 1992, 18, 1.

24. Lanningham-Foster, L.; Chen, C.; Chance, D.S.; Loo, G.; Biol. Pham. Bull. 1995, 18, 1347.

25. Rice-Evans, C.; Miller, N.J.; Methods Enzymol. 1994, 234, 279.

26. Wang, H.; Cao, G.; Prior, R.L.; J. Agric. Food. Chem. 1996, 44, 701.

27. Prior, B.; Cao, G.; Free Radical Biol. Med. 1999, 27, 1173.

28. Cao, G.; Prior, R.L.; Clin. Chem. 1998, 44, 1309.

29. Riber, J.; de la Fuente, C.; Vazquez, M.D.; Tascón, M.L.; Sánchez-Batanero, P.; Talanta 2000, 52, 241.

30. Fuse, T.; Kusu, F.; Takamura, K.; J. Chromatogr. A 1997, 764, 177.

31. Pratt, D. E.; Miller, E. E.; J. Am. Oil Chem. Soc. 1984, 61, 1064.

32. Tada, M.; Matsumoto, R.; Yamaguchi, H.; Chiba, K.; Biosci. Biotechnol. Biochem. 1996, 60, 1093.

33. Kimata, H.; Nakashima, T.; Kokubun, S.; Nakayama, M.; Kitahara, T.; Tanaka, O.; Chem. Bull. Pharm. 1992, 31, 1998.

34. Encarnación, R.; Kenne, L.; Samuelsson, G.; Sandberg, F.; Phytochemistry 1981, 20, 1939.

35. Kimata, H.; Nakashima, J.; Kokobun, S.; Nakayama, K.; Mitoma, Y.; Kitahara, J.; Yata, N.; Tanaka, O.; Chem. Bull. Pharm. 1983, 31, 1998.

Received: May 14, 2002

Published on the web: August 8, 2003

FAPESP helped in meeting the publication costs of this article. 